\title{
Pemberdayaan Dan Pemanfaatan "Toga" Sebagai Produk Minuman Immunostimulan Di Kelurahan Tangkerang Timur Pekanbaru
}

\author{
Putri Indah Chantika ${ }^{1 *}$, Herdina Utami ${ }^{2}$, Hasmalina Nasution ${ }^{3}$ \\ ${ }^{1}$ Prodi Sistem Informasi, Fakultas Ilmu Komputer, UMRI \\ ${ }^{2}$ Prodi Pendidikan Bahasa Inggris, Fakultas Keguruan Ilmu dan Pendidikan, UMRI \\ ${ }^{3}$ Prodi Kimia, Fakultas MIPA dan Kesehatan, UMRI \\ email: 180402054@student.umri.ac.id
}

\begin{abstract}
The community service program is carried out by students in fulfilling one of the programs in University which is also called KKN or Kuliah Kerja Nyata. In this KKN activity, the community can participate in participating in finding solutions to problems that exist in their area so that these problems can be resolved and cooperation is established in local regional development. The main activity carried out in this community service program is the planting of Family Medicinal Plants to be processed into a product that is beneficial for health and enhances immunity. This product is also known as an immunostimulant drink which is named Turmeric Acid Herbal Drink. This activity is carried out offline with the main target being PKK women in the Tangkerang Timur Village area, precisely in Merpati Indah Village. The implementation method used is in the form of socialization which is followed by product manufacturing training. After the socialization and training on making beverage products was carried out, $30 \%$ of the participants who attended were able to understand and have the desire to apply the things that have been conveyed. In this activity there were about 40 participants who were present who were representatives of the PKK women's group. They were very enthusiastic and fully supported this activity, and not a few participants wanted to do the practice in their own homes. Some of the results achieved from this KKN-PPM activity are that it can improve public health and maintain body immunity, and can increase productivity for PKK mothers as well as the availability of several herbal medicines from Family Medicinal Plants.
\end{abstract}

Keywords: PKK mothers, Immunostimulant Drink, Family Medicinal Plants, TOGA

\begin{abstract}
Abstrak
Program pengabdian masyarakat dilakukan oleh mahasiswa dalam memenuhi salah satu program pada Perguruan Tinggi yang disebut juga dengan KKN atau Kuliah Kerja Nyata. Dalam kegiatan KKN ini, masyarakat dapat turut berpartisipasi dalam mencari solusi permasalahan-permasalahan yang ada di daerah mereka sehingga berbagai permasalahan tersebut dapat teratasi dan terjalinlah kerja sama dalam pembangunan daerah setempat. Kegiatan utama yang dilakukan dalam program pengabdian masyarakat ini yaitu penanaman Tanaman Obat Keluarga untuk diolah menjadi suatu produk yang bermanfaat bagi kesehatan dan peningkat imunitas tubuh. Produk ini disebut juga dengan istilah minuman immunostimulan yang diberi nama Minuman Herbal Kunyit Asam. Kegiatan ini dilakukan secara luring dengan sasaran utama ibu-ibu PKK pada wilayah Kelurahan Tangkerang Timur tepatnya di Kampung Merpati Indah. Metode pelaksanaan yang digunakan berupa sosialisasi yang dilanjutkan dengan pelatihan pembuatan produk. Setelah sosialisasi dan pelatihan pembuatan produk minuman dilaksanakan, $30 \%$ dari peserta yang hadir dapat memahami dan mempunyai keinginan untuk menerapkan hal yang telah
\end{abstract}


disampaikan. Dalam kegiatan ini terdapat sekitar 40 orang peserta yang hadir yang merupakan perwakilan dari kelompok ibu-ibu PKK. Mereka sangat antusias serta mendukung penuh kegiatan ini, dan tak sedikit peserta ingin melakukan praktek tersebut di rumah masing-masing. Beberapa hasil yang dicapai dari kegiatan KKN-PPM ini adalah dapat meningkatkan kesehatan masyarakat dan menjaga imun tubuh, serta dapat menambah produktivitas bagi ibu-ibu PKK juga tersedianya beberapa obat herbal dari Tanaman Obat Keluarga

Kata Kunci: Ibu-ibu PKK, Minuman Immunostimulan, Tanaman Obat Keluarga, TOGA

\section{PENDAHULUAN}

Tangkerang Timur merupakan salah satu Kelurahan yang berada di Kecamatan Tenayan Raya, Kota Pekanbaru. Wilayah ini memiliki luas $5 \mathrm{~km}^{2}$ dengan RT yang berjumlah 39 dan RW berjumlah 10 . Wilayah Tangkerang Timur dapat dikatakan mempunyai lahan yang cukup luas dengan sebagian wilayahnya yang masih berupa hutan. Profesi masyarakat disana juga beragam dengan ibu-ibu yang rata-rata berprofesi sebagai ibu rumah tangga. Hasil dari sosialisasi mahasiswa dengan pihak Kelurahan Tangkerang Timur, didapatkan informasi bahwa hal yang menjadi keluhan bagi masyarakat yaitu perihal kesehatan dan ekonomi. Hal ini menjadi suatu yang memprihatinkan disamping seluruh masyarakat sedang berusaha menghadapi pandemi dari segala bidang. Masyarakat pun masih belum dapat mengolah lahan kosong yang menjadi sumber peningkatan ekonomi mereka. Semestinya lahan kosong tersebut dapat digunakan sebagai media bertani untuk bidang kesehatan seperti menanam Tanaman Obat Keluarga guna meningkatkan kondisi kesehatan dan dapat juga dijadikan sebagai sarana peningkatan perekonomian masyarakat dari hasil panen Tanaman Obat Keluarga tersebut.

Terdapat salah satu daerah yang menjadi perhatian dalam pelaksanaan program pengabdian masyarakat ini yaitu Kampung Merpati Indah yang terletak di RT. 05 RW. 06. Diketahui bahwa dalam Kampung Merpati Indah terdapat kelompok ibu-ibu PKK yang kegiatannya saat ini masih belum produktif.
Mengingat Tanaman Obat Keluarga (TOGA) sangat bermanfaat untuk kesehatan, maka diadakannya pemanfaatan TOGA dengan melibatkan kelompok ibu-ibu PKK di Kampung Merpati Indah serta diharapkan mampu mendukung peningkatan kesehatan dan sekaligus pemberdayaan perempuan dalam upaya meningkatkan pendapatan industri rumah tangga. Pembuatan produk minuman immunostimulan ini dapat dimanfaatkan sebagai sarana dalam menjadikan masyarakat yang mandiri dalam menangani permasalahan kesehatan sehari-hari dan sekaligus meningkatkan perekonomian.

\section{METODE PENGABDIAN}

Kegiatan dalam program pengabdian kepada masyarakat kali ini mengenai desa tangguh kesehatan yang dilakukan di Kampung Merpati Indah, Kelurahan Tangkerang Timur. Pelaksanaan program pengabdian ini dilakukan oleh mahasiswa selama satu bulan penuh dari Agustus sampai dengan September. Sasaran utama dari kegiatan pengabdian masyarakat ini yaitu kelompok ibu-ibu PKK pada Kampung Merpati Indah.

Untuk mengawali pengabdian ini, dilakukan sosialisasi dengan pihak-pihak terkait terlebih dahulu. Dilakukan sosialisasi pertama dengan pihak Kelurahan Tangkerang Timur yang kemudian dilanjutkan dengan pertemuan antara mahasiswa, RT, dan RW setempat. Dilaksanakan juga Persiapan Pelatihan Motivasi yang merupakan proses perijinan ke lokasi penanaman hortikultura, 
persiapan tempat pelatihan, pembentukan panitia pelatihan hingga survei lokasi.

Metode yang digunakan dalam pengabdian masyarakat kali ini yaitu dilaksanakan dengan cara sosialisasi hingga mengadakan acara pelatihan untuk pembuatan produk minuman immunostimulan tersebut.

\section{HASIL DAN PEMBAHASAN}

Kegiatan pengabdian masyarakat diawali dengan merancang dan menyusun beberapa program kerja yang akan dilaksanakan selama kegiatan pengabdian. Penyusunan program kerja ini dilakukan bersama dengan seluruh anggota tim dengan tetap mengikuti arahan dan saran dari Dosen Pembimbing Lapangan ibu Hasmalina Nasution, M.Si.

Selanjutnya diadakan sosialisasi bersama anggota kelompok dan juga melibatkan pihak mitra yaitu ibu-ibu PKK dengan melakukan pembahasan mengenai program kerja yang sudah dirancang dan disusun sebelumnya. Pihak mitra dengan tangan terbuka turut antusias dan berpartisipasi dalam kegiatan pengabdian ini. Pihak mitra bersedia menyediakan lokasi yang akan digunakan untuk melangsungkan kegiatan dan turut mengumpulkan sejumlah massa pada saat sosialisasi dan pelatihan pembuatan produk diadakan. Pihak mitra juga bersedia untuk diwawancarai mengenai rangkaian pelaksanaan dalam kegiatan pengabdian masyarakat oleh mahasiswa ini.

Kegiatan selanjutnya yaitu melakukan persiapan peralatan guna mengadakan penanaman bibit Tanaman Obat Keluarga (TOGA) pada lahan kosong yang sudah disediakan oleh pihak mitra. Setelah itu dilakukan sosialisasi dan pelatihan mengenai khasiat TOGA dan cara mengolahnya menjadi suatu produk yang dapat bermanfaat bagi kesehatan dan imun tubuh. Kegiatan ini sepenuhnya diikuti oleh perwakilan kelompok ibu-ibu PKK RT. 05 RW. 06 secara luring.
Kelompok ini sangat antusias mengikuti kegiatan tersebut. Selain cara pembuatan produk, ditunjukkan juga cara mengemas produk dengan baik dan bagaimana cara menyimpan produk tersebut dengan benar.

Kegiatan pelatihan pembuatan produk ini dimulai dari proses pengumpulan bahan baku yang kemudian akan dilanjutkan dengan pemilahan bahan, pencucian bahan, pemotongan, mengolah bahan baku hingga matang menjadi minuman serta melakukan pengemasan.

Kegiatan sosialisasi hingga pelatihan pembuatan produk ini seluruhnya dilakukan oleh mahasiswa dengan mempelajari terlebih dahulu bahan dan materi terkait agar proses kegiatan tersebut dapat benar-benar mendatangkan manfaat dengan baik. Produk yang sudah di produksi dapat menjadi sarana dalam meningkatkan pendapatan industri rumah tangga dengan memasarkan produk tersebut kepada kelompok ibu-ibu Majelis Taklim atau memasarkannya di tempattempat usaha lainnya. Dalam pemasaran ke beberapa tempat usaha, tentunya masyarakat harus mendapat izin terlebih dahulu dari Dinas Kesehatan Kota Pekanbaru guna memastikan produk tersebut aman untuk dikonsumsi.

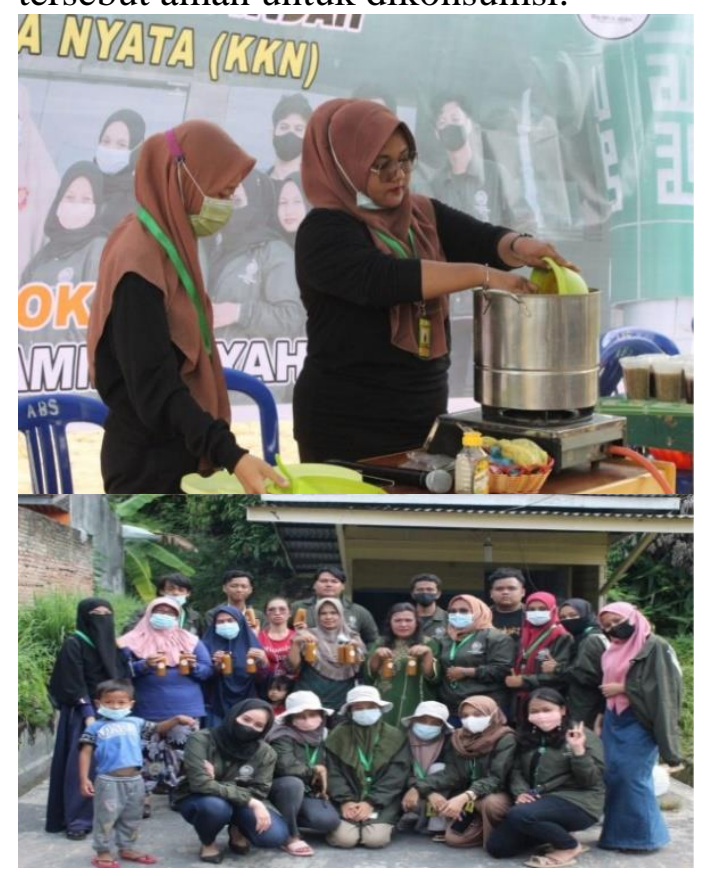



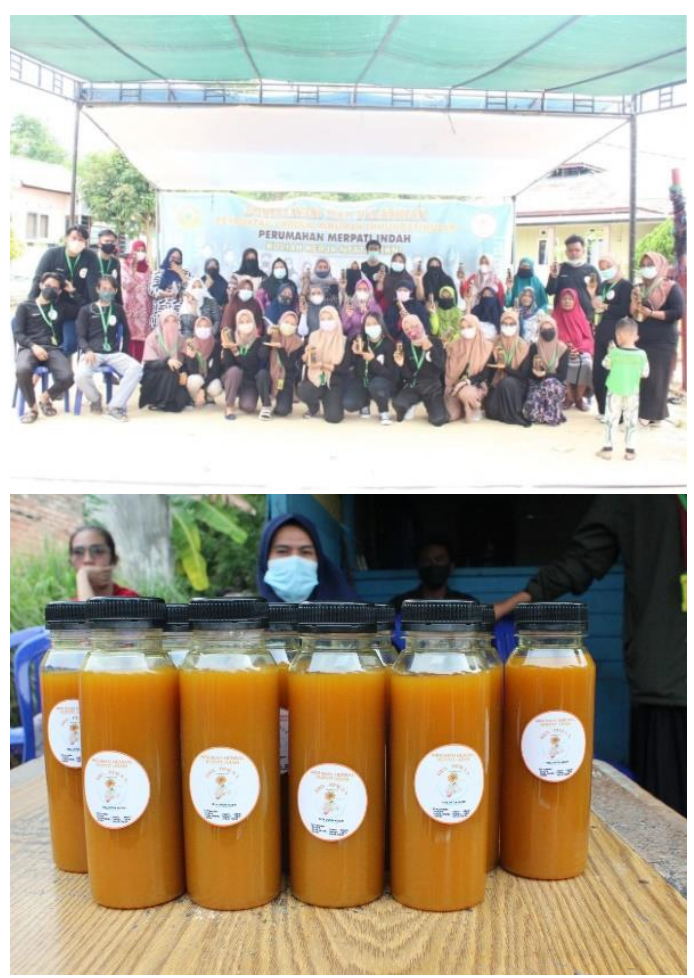

Gambar 1. Proses dan Pengolahan Produk

\section{SIMPULAN}

TOGA (Tanaman Obat Keluarga) merupakan kegiatan memanfaatkan lahan untuk ditanami dengan berbagai tanaman yang bermanfaat sebagai obat. Pengolahan TOGA menjadi suatu produk kesehatan merupakan langkah yang tepat dalam mendukung peningkatan kesehatan dan sekaligus pemberdayaan perempuan dalam upaya meningkatkan pendapatan industri rumah tangga. Salah satu produk yang dapat diolah dari TOGA ini yaitu produk minuman immunostimulant yang kami beri nama Minuman Herbal Kunyit Asam. Pembuatan produk minuman immunostimulan dapat dimanfaatkan sebagai sarana dalam menjadikan masyarakat yang mandiri dalam menangani permasalahan kesehatan sehari-hari sekaligus menningkatkan perekonomian.

Dalam kegiatan sosialisasi dan pelatihan yang telah dilakukan terdapat sekitar 40 orang peserta yang mengikuti dan antusias dengan penjelasan yang diberikan. Banyak dari peserta yang tertarik dan ingin mengulangi pembuatan produk tersebut di rumah masing-masing. Minuman Herbal Kunyit Asam berhasil diproduksi sebanyak kurang lebih 50 botol selama masa kegiatan.

\section{UCAPAN TERIMAKASIH}

Kami mengucapkan terima kasih kepada LPPM UMRI serta kepada pihakpihak mitra, Perangkat Kelurahan Tangkerang Timur, ibu-ibu PKK dan masyarakat RT. 05 RW. 06 yang telah turut serta untuk berpartisipasi dalam mensukseskan serta melancarkan kegiatan program pengabdian kepada masyarakat ini.

\section{DAFTAR PUSTAKA}

[1]. Saharuddin, 2017, Pengabdian KKNPPM Desa Wonorejo Kecamatan Mangkutana Kabupaten Luwu Timur. Jurnal Ilmiah Pengabdian Masyarakat, Volume 1, No. 1

[2]. Hasanah, S., Wibowo, D., dan Aulifa, D., 2020, Lindungi Imunitas Masyarakat Dengan Minuman Herbal. Jurnal Pengabdian Kepada Masyarakat, Volume 3, Nomor 2

[3]. Febriansyah, R., 2017, Pemberdayaan Kelompok Tanaman Obat Tanaman Keluarga Menuju Keluarga Sehat Di Desa Sumberadi, Mlati, Sleman. Jurnal Berdikari, Vol. 5, No. 2

[4]. Aseptianova, 2019, Pemanfaatan Tanaman Obat Keluarga Untuk Pengobatan Keluarga Di Kelurahan Kebun Bunga Kecamatan SukaramaiKota Palembang, Jurnal Batoboh, Vol. 4, No. 1 